\title{
Aplikasi Layanan Pelanggan Jasa Dalam Bidang Kelistrikan Berbasis SMS Gateway Pada PT. PLN Persero Pangkalpinang
}

\author{
Franst Albert Tittaley \\ Program Studi Teknik Informatika \\ STMIK Atma Luhur \\ J1. Jend. Sudirman, Selindung, Pangkalpinang \\ franstittaley@gmail.com
}

\author{
R. Burham Isnanto Farid \\ Program Studi Teknik Informatika \\ STMIK Atma Luhur \\ Jl. Jend. Sudirman, Selindung, Pangkalpinang \\ burham@atmaluhur.ac.id
}

\begin{abstract}
Abstrak-Perkembangan teknologi informasi dan komunikasi dalam kehidupan sehari-hari tentunya sangat berpengaruh bagi masyarakat. Berbagai layanan komunikasi, seperti SMS (Sort Message Service) yang memungkinkan masyarakat untuk mendapatkan atau mengirimkan informasi kapan saja dan dimana saja saat dibutuhkan. Penggunaan fasilitas SMS pada setiap handphone juga relatif mudah dan bisa dioperasikan oleh banyak orang. Berawal dari teknologi komunikasi tersebut maka dibuatlah suatu aplikasi layanan pelanggan berbasis SMS Gateway pada PT. PLN (Persero) Pangkalpinang yang bertujuan untuk memberikan kemudahan dalam mengakses informasi secara mudah, cepat, dan murah.Metode penelitian yang digunakan adalah pengumpulan data yang terdiri dari observasi, wawancara, studi kepustakaan, analisa sistem dimana pada analisa sistem penulis menganalisa sistem yang ada, perancangan sistem, coding, compiler, testing dan implementasi program. Dengan adanya aplikasi ini dapat memudahkan pelanggan yang menggunakan jasa kelistrikan untuk me-request dan mengetahui informasi mengenai tagihan listrik, informasi no telphone per area sehingga menjadi lebih mudah dan lebih cepat dalam mendapatkan atau menyampaikan informasi kapan pun dan dimana pun selagi masih terhubung ke jaringan seluler sehingga pelanggan tidak perlu datang ke PT. PLN (Persero). Aplikasi ini juga sangat membantu pihak instansi dalam memberikan informasi secara otomatis kepada semua pelanggannya tanpa pemberitahuan informasi melalui lisan maupun brosur edaran sehingga biaya yang dikeluarkan lebih murah.
\end{abstract}

Kata Kunci- SMS, aplikasi, informasi jasa kelistrikan, broadcast

\section{Pendahuluan}

Manfaat dan perkembangan teknologi informasi dan komunikasi dalam kehidupan sehari-hari tentunya sangat berpengaruh bagi masyarakat. Secara langsung ataupun tidak, teknologi informasi dan komunikasi telah menjadi bagian penting dari berbagai bidang kehidupan. Manusia tidak dapat disebut sebagai makhluk sosial, jika tidak berinteraksi dan berkomunikasi dengan manusia lainnya. Melalui komunikasi manusia banyak mendapatakan informasi yang belum diketahuinya, sehingga menambah pengetahuan manusia itu tersendiri. Kebutuhan akan informasi telah mendorong manusia untuk mengembangkan teknologi yang dapat membantunya mendapatkan informasi secara cepat dan tepat dari berbagai tempat.

Salah satu produk teknologi informasi yang mengalami pertumbuhan pesat adalah telekomunikasi menggunakan perangkat Handphone atau telepon seluler yang digunakan untuk mempermudah komunikasi jarak jauh dengan pengguna mobilitas yang tinggi. Handphone memiliki kelebihan lain dibandingkan dengan telepon biasa. Handphone dinilai lebih efektif dan efisien. Belum lagi perkembangan teknologi handphone sekarang ini mulai dari fasilitas pengiriman data melalui SMS, MMS, Email ataupun fasilitas Bluetooth dan Infrared. Mulai dari fitur gambar hingga Mobile TV dan video call. Dari segala fasilitas yang ada pada handphone yang paling banyak digunakan adalah SMS. Di dalamnya terdapat sebuah metoda komunikasi yang dinamakan layanan pesan singkat atau lebih sering disebut SMS (Short Message Service).

SMS (Short Message Service) yaitu layanan dari telepon selular yang memiliki sebuah konsep pengiriman informasi berbasis teks. Hal ini juga yang menjadikan SMS sebagai media penyampaian informasi yang efektif untuk menyampaikan dan menyebarkan informasi kepada pelanggan yang membutuhkan informasi secara cepat dan akurat.

\section{LANDASAN TEORI}

\section{A. Pengertian Aplikasi}

Aplikasi adalah hasil terjemahan program, berupa kode yang dipahami oleh mesin. Pada sistem windows, hasil terjemahan program disimpan kedalam file berektensi.exe. File inilah yang bisa dijalankan oleh pemakai.[Abdul Kadir 2014:16] Pada java, hasil terjemahan berupa bytecode.

\section{B. SMS Gateway}

Menurut Ardana (2004:35) SMS Gatewaymerupakan suatu alat yang fungsinya sebuah penghubung atau jembatan antara aplikasi atau sistem dengan mobile phone. Pesan-pesan SMS dikirim melalui telepon genggam kepusat pesan yaitu Short Message Service Centre (SMSC), disini pesan disimpan dan 
dikirim selama beberapa kali. Setelah sebuah wakt yang telah ditentukan, biasanya satu atau 2 hari, lalu pesan dihapus.

\section{SMS (Short Message Service)}

SMS (Short Message Service) adalah merupakan salah satu layanan pesanteks yang dikembangkan dan distandarisasi oleh suatu badan yang bernama ETSI(European Telecommunication Standards Institute) sebagian dari pengembangan GSM (Global System for Mobile Communication) Phase 2, yang terdapat pada dokumentasiGSM 03.40 dan GSM 03.38.

\section{Perancangan Sistem}

Sistem berasal dari bahasa Latin (systēma) dan bahasa Yunani (sustēma) adalah suatu kesatuan yang terdiri komponen atau elemen yang dihubungkan bersama untuk memudahkan aliran informasi, materi atau energi. Istilah ini sering dipergunakan untuk menggambarkan suatu set entitas yang berinteraksi, dimana suatu model matematika seringkali bisa dibuat.[Hajib Hanani,2008: 14]

\section{AnAlisa MaSAlaH}

\section{A. Perencanaan}

1) Objektive Proyek

Objektifitas proyek yaitu hal-hal yang berisi tentang tujuan pelaksanaan proyek, hal-hal yang melandasi terciptanya sebuah proyek serta manfaat dan tujuan proyek secara rinci. Objective proyek perancangan aplikasi layanan pelanggan jasa kelistrikan PT. PLN (Persero) berbasis SMS gateway adalah:

- Merancang aplikasi layanan pelanggan jasa kelistrikan PT. PLN (Persero) berbasis SMS gateway yang bisa dipahami oleh administrator.

- Merancang aplikasi layanan pelanggan jasa kelistrikan PT. PLN (Persero) berbasis SMS gateway untuk memenuhi kebutuhan pelanggan atau masyarakat.

- Merancang aplikasi layanan pelanggan jasa kelistrikan PT. PLN (Persero) berbasis SMS gateway yang dapat digunakan oleh pelanggan atau masyarakat.

\section{2) Identifikasi Stakeholder}

Stakeholder ini juga bisa mempengaruhi jalannya proyek dan deliverables proyek. Beberapa stakeholder pada lingkup manajemen proyek antara lain:

- Customer

- Sponsor

- Manajer Portfolio, Manajer Program, Manajer Proyek

- Manajer Operasional

- Vendor

- Dan lain-lain

\section{B. Analisa Sistem}

1) Analisa Proses Bisnis Aplikasi yang Sedang Berjalan

Informasi tentang aplikasi yang sedang berjalan sangatlah penting dalam proses perancangan aplikasi karena dapat diketahui sejauh mana aplikasi yang sedang berjalan sekarang supaya bisa memenuhi kebutuhan pelanggan sehingga aplikasi yang belum terpenuhi dapat diberikan solusinya dan diterapkan dalam tahap perancangan sistem.

- Analisa proses layanan pelanggan yang sedang berjalan pada PT.PLN (Persero) yaitu :

- Pelanggan menelepon ke kantor atau datang ke pemasangan KWh yang ada dirumah dan menanyakan informasi tentang tagihan kelistrikan, informasi no telephone PLN kode area di Bangka atau informasi pasang baru.

- Pengaduan listrik PLN jika ada permasalahan atau gangguan yang mengharuskan pelanggan atau masyarakat datang ke Kantor PLN terdekat atau menelphone ke bagian gangguan alangkah baiknya diberitahukan terlebih dahulu jika ada

- Keadaan darurat dimana jika terjadi musibah seperti banjir dimana di tahun 2016 sudah terjadi dua kali banjir di tempat-tempat tertentu yang di landa banjir, jika pelanggan atau masyarakat semuanya bisa melakukan komunikasi langsung jadi lebih cepat pemadaman listrik ke bagian wilayah yang dilanda banjir.

\section{2) Activity Diagram}

a) Proses Info Tagihan Listrik

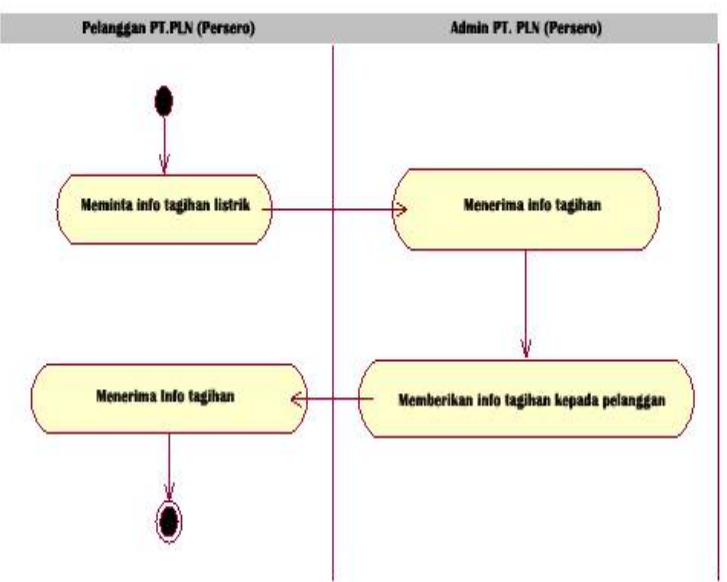

Gambar 1. Activity Diagram Info Tagihan Listrik

b) Proses info no telephone PT. PLN (Persero) terdekat 


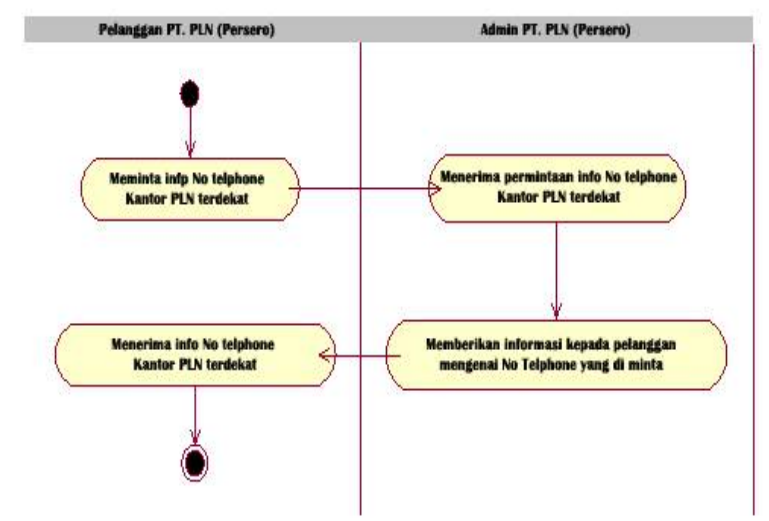

Gambar 2. Activity Diagram Info No Telephone PT. PLN (Persero)

\section{DESAIN DAN IMPLEMENTASI}

\section{1) Rancangan Basis Data}

a) $E R D$

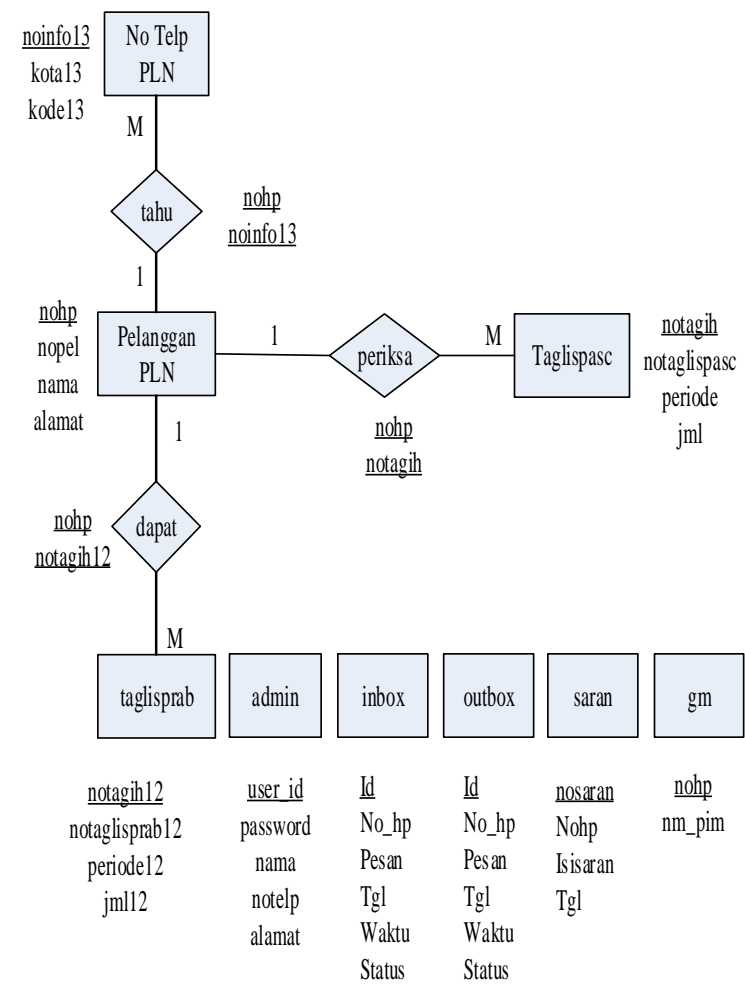

\section{b) Transformasi ERD ke LRS}

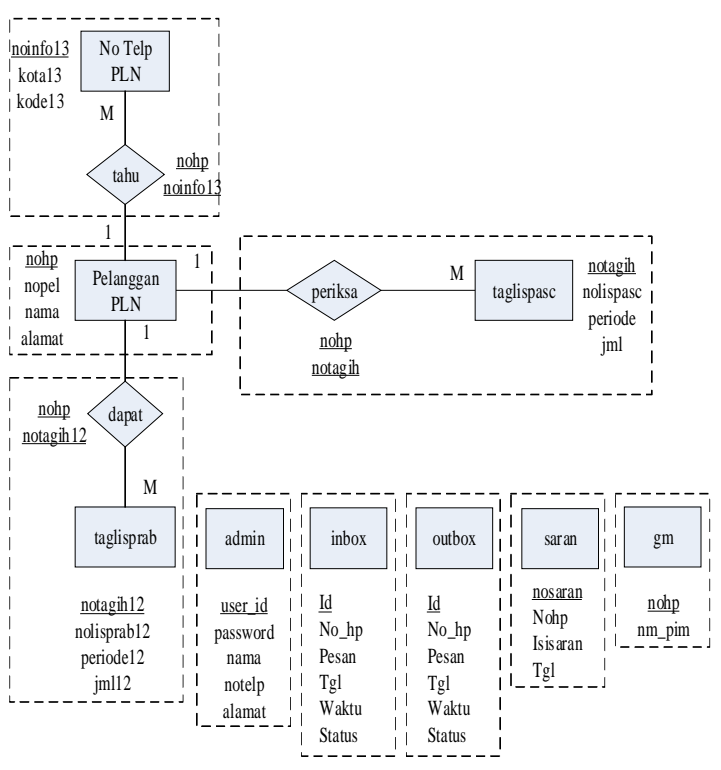

Gambar 4. Transformasi ke LRS

\section{c) $L R S$}

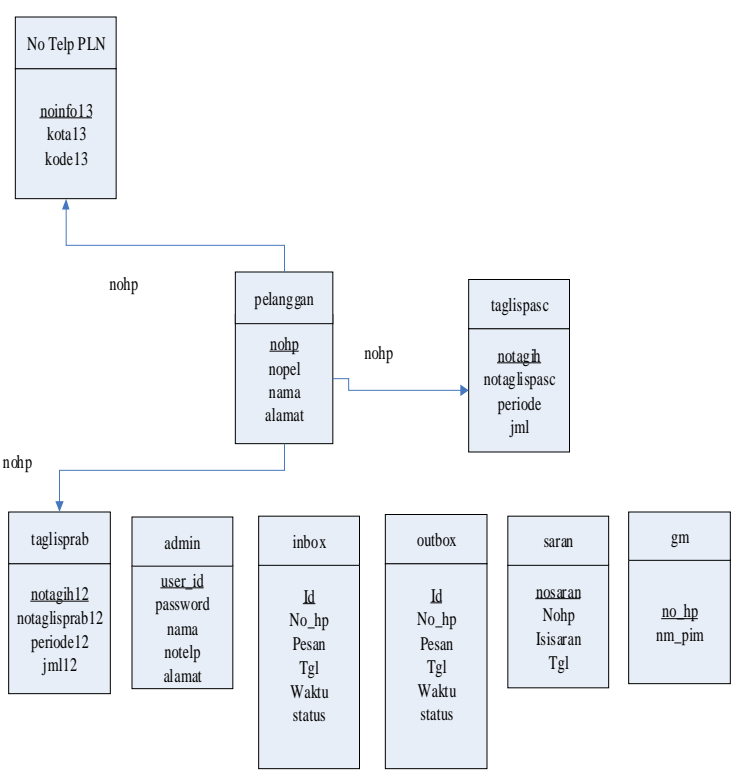

Gambar 3. ERD

Gambar 5. LRS 


\section{2) Rancangan Masukan}

- Data Pelanggan PT. PLN (Persero)

- Data Tagihan listrik pascabayar

- Data tagihan Tagihan Listrik Prabayar

- Data No Telphone Kantor PLN area

\section{3) Rancangan Keluaran}

- SMS Informasi tagihan listrik pascabayar

- SMS Informasi Tagihan Listrik Prabayar

- SMS Informasi kode area

\section{Penutup}

\section{A. Kesimpulan}

Untuk pengembangan Aplikasi Layanan Pelanggan Jasa Kelistrikan berbasis SMS Gateway pada PT.PLN (Persero) Pangkalpinang ini menjadi lebih sempurna, maka dapat diambil kesimpulan sebagai berikut:

- Aplikasi layanan pelanggan berbasis SMS gateway ini dapat memudahkan pelanggan yang menggunakan Jasa Kelistrikan untuk me-request dan mengetahui informasi mengenai tagihan listrik pascabayar, tagihan info listrik prabayar, informasi no telephone pengaduan gangguna area sehingga menjadi lebih efisien karena pelanggan tidak perlu datang ke PT. PLN (Persero) tersebut. Serta pelanggan dapat memberikan kritik juga saran kepada instansi terkait.

- $\quad$ Semua bentuk transaksi dan informasi dari aplikasi ini bisa diakses dimanapun dan kapanpun waktu yang diinginkan pelanggan selagi masih terhubung dengan jaringan ponsel.

- Aplikasi yang dibuat ini sangat membantu pihak instansi PT. PLN (Persero) dalam memberikan informasi secara otomatis kepada semua pelanggannya tanpa pemberitahuan informasi melalui lisan maupun brosur edaran yang banyak memakan waktu dan media kertas.

- Pelanggan tidak perlu datang ke Customer Service untuk merubah nomor handphone, cukup dengan mengupdate langsung melui format SMS yang telah ditentukan.

- Aplikasi yang dibuat ini masih membutuhkan administrator untuk menjalankan sistem SMS broadcast.

\section{B. Saran}

Sebagai bahan pertimbangan dalam pengembangan Aplikasi Layanan Pelanggan Jasa Kelistrikan berbasis SMS Gateway pada PT.PLN (Persero) Pangkalpinang, maka dapat diambil saran-saran sebagai berikut:

- Spesifikasi kebutuhan program harus dipenuhi sehingga aplikasi layanan pelanggan berbasis SMS ini bekerja dengan benar dan dengan waktu proses yang cepat.
- Pihak yang terkait harus bertanggung jawab dalam merawat dan mengawasi pemeliharaan sistem, agar sistem dapat berjalan dengan baik dan lancar.

- Informasi yang diakses melalui Aplikasi Layanan Pelanggan jasa Kelistrikan berbasis SMS ini masih terbatas bagi pelanggan, maka perlu ditambah lagi informasi-informasi lain yang lebih complete untuk diakses lagi bagi pelanggan.

- Perlu ditambahkan lagi fitur-fitur yang lebih lengkap, sehingga mampu memenuhi kebutuhan yang lebih kompleks.

\section{DAFTAR PUSTAKA}

[1] Abusajid. 2006. Mengenal SMS ( Short Message Service). http://www.mobileindonesia.net/mengenal-sms-shortmessage-service/. diunduh 13 Mei 2016.

[2] Bambang, Haryanto. 2003. Esensi-Esensi Bahasa Pemrograman Java. Informatika : Bandung.

[3] Cahyono, Setiyo. 2006. Panduan Praktis Pemrograman Database Menggunakan MySQL dan JAVA. Informatika: Bandung.

[4] Deitel Harvey. M. And Paul. J. Deitel. 2003. Java How To Program, Fifth Edition. Prentice Hall : New Jersey.

[5] Gunawan Ferry. 2003. Membuat Aplikasi SMS Gateway Server dan Client Dengan Java dan PHP. Elex Media Komputindo: Jakarta.

[6] Martine, Inge. 2003. Microsoft SQL Server 2000. PT. Elex Media Komputido : Jakarta.

[7] Mulyana Y.B, S.Kom. 2003. Trik Membangun Situs Menggunakan PHP dan MYSQL. Elex Media Komputindo: Jakarta.

[8] Munawar. 2005. Pemodelan Visual dengan UML. Graha Ilmu : Jakarta. 